\title{
A COMPARATIVE REVIEW OF INDIAN AND SAUDI ARABIAN SOCIAL WELFARE SCHEMES \\ Nannapaneni Siva Kumar ${ }^{1}$, Mohammad Imdadul Haque ${ }^{2}$ \\ ${ }^{1}$ Department of English, Koneru Lakshmaiah Education Foundation, Vaddeswaram, AP, India, ${ }^{2}$ College of Business Administration, Prince Sattam Bin Abdulaziz University, AlKharj, Saudi Arabia. \\ Email: ${ }^{1}$ dr.sivakumar.n@gmail.com, ${ }^{2}$ m.haque@psau.edu.sa
}

Article History: Received on $17^{\text {th }}$ August 2019, Revised on $30^{\text {th }}$ September 2019, Published on $07^{\text {th }}$ November 2019

\begin{abstract}
Purpose of the study: The aim of the study is to find the similarities between the welfare schemes of Indian and Saudi governments, and the burden of these schemes and their impact on society. This study aims to compare and contrast the welfare schemes of two altogether different types of economy.
\end{abstract}

Methodology: This study applies the methodology of comparative analysis by employing descriptive analysis to study both the similarities and dissimilarities of the welfare schemes of Saudi Arabia and India.

Main Findings: Indian and Saudi governments have been spending a lot of welfare schemes of their respective GDPs. The intention of these governments is to help the poor to lead a minimum quality of life. Though the intention is genuine and appreciable, in terms of implementation, the two governments have not yet achieved any desired results even after 60 years of introduction.

Applications of this study: India and Saudi Arabia can learn from each other in designing and distributing welfare schemes like Saudi Arabia should focus to have targeted compensation and India to use its unique identification numbers to reduce leakages in its schemes. Instead of focusing on giving subsidies, it is better to devise a strategy with a timeframe to reduce poverty by creating many opportunities for the poor to improve their standard of living.

Novelty/Originality of this study: The novelty in this study is a comparison of welfare schemes between two countries with two different types of political systems. While both countries are developing in nature, Saudi Arabia falls under a very high-income category country and India falls under the lower-middle-income category country.

Keywords: welfare schemes, poor, India, Saudi Arabia, subsidized food, pension, subsidized housing, subsidized healthcare, subsidized education.

\section{INTRODUCTION}

Welfare is a government program that supports the needy who cannot support themselves. The Bismark government introduced social security in the late 19th century when it was Imperial Germany (1871-1918). Later many countries in the world have social welfare schemes for the poor people in their respective societies. The motto of these schemes is to see that the poor should not suffer for minimum requirements such as food, shelter, education, etc. Though these welfare schemes are a burden to all the governments, they provide them to the specific individuals who are eligible for such schemes. There is nothing wrong with helping the poor in the name of social welfare schemes. In fact, on humanitarian grounds, governments should support the poor.

Indian and Saudi governments provide a large number of welfare schemes. There are some commonalities and a few differences in welfare schemes such as education, health, housing and pension that are provided by these two governments. It is obvious that the burden of these schemes should be borne by the remaining sections of the society. Saudi Arabia is a high-income country, whereas India is a developing country. Although there are many differences such as culture, size of the country, population and democracy - the monarchy of these countries; they can learn from each other in designing and distributing the welfare schemes.

The reduction of poverty in developing countries always links either with pro-poor economic growth or social protection policies. So, social protection plans must carefully be designed with the nature of the growth process (Berry, 2013). He further says the poor are vulnerable rely on both the 'primary distribution of income' and the 'secondary (or final) distribution of income'. The economic behavior of individuals and the economic context is reflected by the primary income distribution.

To promote a better chance from development to an individual, the role of social security policies in developing countries must be extended (Guhan, 1994). If that is done so, the negative outcomes of development would be addressed by the social protection policies and promote equal opportunities. Thus, developing countries should focus on reducing and mitigating the vulnerability with the help of social security policies and see that social security policies are integrated within the overall strategy rather than implementing as individual programs (Kabeer, 2002).

The concept of poverty would certainly be different in both those countries. For India, poverty is an absolute value wherein a person with a level of income below a designated level would be termed as poor. But for a rich country, it would not be an absolute value, rather a relative value. It can be better understood in terms of Al-Damigh (2014)who visualizes the Kingdom's principal concern to be sufficiency of augmented basic needs which makes sure a proper standard of living. 
Though there has been a downfall in the oil prices recently, studies suggest continuing the expenditure on social security and welfare (Alsayyad, 2017).

The economic, social and even political structure of the countries under study namely, Saudi Arabia and India are poles apart. GDP per capita is $\$ 54,800$ in Saudi Arabia whereas in India it is $\$ 7,200$ (The World Factbook, 2018). In 2016, population density for Saudi Arabia is 15.01 people per square $\mathrm{km}$ while for India it is a whopping 445 people per square $\mathrm{km}$ (The World Bank, 2017). Saudi Arabia has a monarchy system while India is the largest democratic country in the world. Despite these differences in the basic structure of the economy, both these countries look after the unprivileged population through social welfare schemes.

The oil prices fell from 2014 to 2016, the expenditure on Social Security \& Welfare Services also decreased. It is more evident when social expenditure is seen as a percentage of GDP. The ratio was $0.18 \%$ is 2014 . It declined to $0.17 \%$ in 2015 and further to $0.12 \%$ in 2016 (Table 1). This indicates that even a rich country with a high per capita level of income can also have a case where its expenditure on social security and welfare services can fall.

Both these countries need to structure their welfare schemes to make it most efficient. It is obvious for India as allocating money for social welfare schemes are an added burden on economic growth. In the case of Saudi Arabia, it is different as it is a rich country but the recent downfall in the oil prices will certainly put a strain on the economy. Towards this, the objective of this study is to study a sample of the welfare schemes available in these two countries. The idea behind this study is to come up with strategies of one country that can be used by the other country. And the researchers believe that either of the two countries can learn from each other's experiences.

\section{LITERATURE REVIEW}

Though there are several comparative analyses on social security, previously there was no systematic study. Euvrard's can be considered a pioneer. Euvrard researched on principles of the minimum income schemes in Europe (Euvrard,1989). Later Liebfried did research on social welfare's range of assistance schemes in Europe (Liebfried, 1991).

Jacobs (1998) did research on the social welfare schemes of five East Asian countries. He analyzed the overall costs of welfare schemes. The above five countries are compared with some of the major western countries with respect to cost and income distribution.

Bradshaw and Finch (2002) in a research paper on comparison of child benefit packages they compared as many as 22 countries. The study focused on variations in the structure and level of those packages in all those countries.

Sengoku (2003) compared the pension schemes of selected European countries. He found that Hungary and Poland have a different pension system when compare to the Czech Republic and Slovenia. The difference was that in Hungary and Poland there is a mandatory multi-pillar system while the Czech Republic and Slovenia are still following the traditional Pay-as-you-go system without any kind of major reform.

Schubert and Martens (2005) studied the welfare schemes for European countries. They found that there are common characteristics among the European countries' social and welfare systems. Though there are many countries in Europe and having their own welfare systems, there are similarities in those systems such as benefits for traditional risks; prominence on social protection; residual safety nets; passive transfers at the time of non-employment, etc.

Haggard and Kaufman (2008) compared Latin America's social security spending with East Asia's minimalist welfare states. They found in the comparison that Latin America focuses on curative health care whereas Asia spends more on basic health care. In education, there is not much difference in spending levels between the two regions. Asia focused on retaining the students at least to fifth grade in schools whereas Latin America emphasized on secondary education

Ebbinghaus (2012) reviewed the last two decades of' literature on comparing welfare state regimes. Focused on the advantages and shortfalls of comparing welfare states and the main methodological questions.

Bohle and Greskovits (2017) studied the welfare schemes in the Baltic and Visegrad states. They found that there was no equality in Baltic States welfare systems whereas Visegrad states had equality. The authors reported that the Baltic States have low social inclusiveness and low social expenditure while Visegrad states have addressed inequalities well.

Dobelniece (2017) is of the opinion that researchers have increased their focus on comparative analysis on social assistance. He pointed out the complexity involved in the comparative analysis of social assistance. He focused on descriptive analysis of literature and statistical data in his paper

The review of existing literature points out that there are some studies that compared the developmental schemes of countries. But to the best of authors' knowledge, there are no such studies covering the countries of interest of this study, that is, Saudi Arabia and India.

\section{METHODOLOGY}

This study is primarily based on secondary data. The method applied here is to perform comparative analysis. It is a "systematic and contextual analysis" to compare the occurrence between countries (Kennet 2001). This particular 
methodology has been widely used by (Jacobs, 1998;Bradshaw and Finch, 2002; Dobelniece, 2017). This helps in seeking "explanation for similarities and differences" which helps in generalization, increased awareness and understandings of different social features across countries (Hantrais, 1995). These cross-country comparative studies describe, evaluate and record dissimilar countries' welfare arrangements, their exact policies or their approach to "common issues" (Mabbett and Bolderson,1999). To summarize, this method is a typology to summarize "commonalities and differences" (Ebbinghaus, 2012).

\section{THE FOLLOWING SUBSIDIES OF INDIA AND SAUDI ARABIA ARE COMPARED}

\section{Subsidized Food}

\section{A. India}

During the Second World War, under British rule, the first welfare scheme was launched in India in 1944. Under that scheme subsidized food and non-food items were distributed to India's poor. When India got its independence in 1947, this scheme was re-launched in the current form. Since then many welfare schemes were launched and provided to the poor with the object of empowering marginalized and vulnerable communities. According to the Indian government, $21.9 \%$ of its population is below its official poverty limit (Kaul, 2014).

Schemes in different sectors were introduced such as food, pension, education, agriculture, medical, electricity, petroleum, housing, etc. Under each sector, there are many schemes. Subsidized food is given to the Below Poverty Line (BPL) people through Public Distribution System (PDS) one of the largest welfare institutions in the world. Though the Indian government proudly claims that PDS is one of the largest welfare institutions in the world, there are leakages and distortions across the subsidy system that still result in wasted government resources. Rich households are benefiting more than poor households because of the wastages in the current subsidy system (ENS Economic Bureau, 2015). The 20142015 India Budget Report highlighted that it is regressive that rich households are benefiting more than the poor.

The world bank report states that the benefits of PDS for the poor have been limited by studying the National Sample Survey data is confirmed. Diversion of grains and Leakage in the PDS are high. Households receive government released grains just over $\mathbf{4 1 \%}$, this is worse with some states. Leakage of grains is at $58 \%$ nationally, the Planning Commission has estimated this in 2001 (The World Bank, 2011).

Recently India linked the PDS system with Aadhar (Unique Identification Authority of India) which will plug the leakages in the PDS system.

\section{B. Saudi Arabia}

The agricultural production of Saudi Arabia is not enough to meet domestic needs. So, Saudi imports food for its domestic needs. Rice is the staple food for Saudi people. So, the government takes the burden of the rice subsidy. As per the domestic demand for the rice, it imports most of the quantity. Unfortunately, the rice subsidy benefits those on low and high incomes alike. Because of the board subsidies, there are supply distortions such as the case with wheat and flour over the past few months (Sfakianakis, 2008). The high growth of the population puts more pressure on the government for more subsidies in the coming years.

The second most staple food for Saudi is bread after rice. Saudi stood the world's top in the consumption of bread. It constantly imports wheat from other countries. Saudi had imported more than 3 million tons of wheat by the end of 2016 . For the past 35 years, there is no change in the price of bread by the Saudi government though there are changes in the materials used in making bread, which has increased almost 300 percent and the price of energy too increased (Editorial, 2017).

To subsidize food prices in the country Saudi Arabia will spend more than SR12 billion According to a study, though from the perspective of the per capita basis subsidies are lower than the late 1970s, actually budgeted subsidies are on the rise in Saudi Arabia (Sfakianakis, 2008).

\section{Subsidized Pension}

\section{A. India}

India has been paying old-age support since ancient times. The old age security dates to the 3rd century B.C. in India. People who completed forty years of service had to be paid half of the wages by a king said by Sukraniti (Gayithri, 2007). Royal Commission on civil establishments during the British colonial rule paid civil service pension. The 1919 and 1935 Acts of the India government made further provisions to the public sector working population. Post-independence, several provident funds were also set up to extend coverage among the private sector workers (Goswami, 2001).

All the public sector employees get a pension from the government. Employees of the state government get a pension from the state government. Whereas employees of the central government are paid by the central government. According to Kaul (2015), only salaries and pension bill of the central government has gone up to $13.39 \%$ of the total expenditure in 2015-16. India's population is 1.3 billion and the central government is spending more than $13 \%$ of its expenditure on only 8.8 million employees. Thus, spending is concentrated on a certain section of the population and their families. 
According to the global pension sustainability index, India ranks poor with $47^{\text {th }}$ out of 50 countries. Nandi (2016) says the Indian government spends over $2 \%$ of its GDP on pensions which is more than what it spends on defense and almost double on food security. Governments had anticipated this pension problem much earlier. They introduced a new pension system since 2004 to reduce the burden of the pension bill. According to the new pension system, governments pay a pension to their employees, who employed with them prior to 2003. Employees (except armed forces) hired by the governments since 2004 are mandated to contribute themselves for their pension. Kudva says on the positive side, the direct pension burden of the government will come down to 0.7 percent of GDP by 2030 from 2.2 percent of GDP currently. (Crisil, 2015)

Since 2004, the new pension scheme has been running smoothly, unfortunately, vote bank politics have crept in recently and some political parties in some states are promising old pension system to the government employees. Now state government employees are demanding old pension scheme pan India.

Apart from public sector employees, some others also get free pensions from central and state governments they are called social pensions. Crisil (2015) reports that the overall cost of social pensions may jump up to 4.1 percent of the GDP by 2030. This is almost $1 \%$ more than the expenditure on education. Different pensions are provided under social pension schemes such as old-age pension, widow pension, and disability pensions.

A related study reported, "universal social pension scheme for elderly in India is remarkably higher than the old scheme Indira Gandhi National Old Age Pension Scheme (IGNOAPS). In short-term an increase in pension benefits either by a single adjustment factor or combined adjustment factors but at a cost of the remarkable increase in public expenditure requirements" (Ranganathan, 2017. pp.89-116).

The eligibility criteria for social pensions as of 2007 for the old-age pension divorced and widowed pension and disability pension in the state of Rajasthan is shown in panel A of Table 2. The benefit level of old-age pension and joint old age pension at different periods of time is explained in panel B of Table 2 (The World Bank 2008).

HelpAge India, (2007) in their study on the social pension in India, found that though it is a good scheme indeed, but it does not always benefit the intended recipients. There are leakages to this scheme like, bogus, underage people, middle class and even some rich are benefitting illegally. If the government does not focus on leakages, it must pass burden onto taxpayers. In addition to the above-mentioned pension schemes, some state governments have started offering unemployment pension for the youth recently again for the vote bank.

\section{B. Saudi Arabia}

Old-age pension and other pensions are growing in Saudi Arabia. There is growing pressure on public finances and government debt over the next three decades because of the country's growing elderly population. There are no government reforms to contain the cost of age-related spending, according to Standard \& Poor's 'Global Ageing Report 2016 .

The population of Saudi Arabia will grow rapidly to 46 million from 32 million between 2015 and 2050 as Standard \& Poor has forecasted. The proportion of elderly people will rise from today's 3 percent to 15 percent of total inhabitants over the same period (Augustine, 2016).

Standard \& Poor Global Ratings reports, "If the government of Saudi Arabia does not take any policy action, it will lead to a rapid increase in country's net debt ratio to 340 percent of GDP by 2050 because age-related government expenditure on pensions and health care would rise from today's 6 percent to 14 percent of GDP by 2050" (Augustine, 2016).

The aging population of Saudi Arabia in 2015 was 4 percent, it will raise to 23 percent by 2050. There will a significant pressure on economic growth and public finances probably by an aging population. Demand for state pensions could increase (Augustine, 2016). "Standard \& Poor analysts estimated that in 2015 three percent of Saudi Arabia's age-related pension projected to rise to about 9 percent in 2050 as the bulk of spending will go toward pension outlays (Augustine, 2016).

\section{Subsidized Housing}

\section{A. India}

Next, housing subsidy there are many housing schemes in India. Central government schemes like Pradhan Mantri Awas Yojana (PMAY) (Urban), Pradhan Mantri Gramin Awas Yojana and Rajiv AwasYojna. Different state governments housing schemes are such as Delhi Development Authority Housing Scheme, 2018 by Delhi state government, Tamil Nadu Housing Board Scheme (TNHB) by Tamil Nadu state government, Maharashtra Housing and Area Development Authority (MHADA), 2018 by Maharashtra state government and NTR Urban Housing Scheme by Andhra Pradesh state government etc. Different subsidies are being offered under different housing schemes mentioned above. Two schemes have been explained in this paper below. 
Pradhan Mantri Gramin Awas Yojana by the central government focuses on providing houses for the homeless poor. The government has the objective of building 10 million houses by 2022 with the assistance of state governments. 2.88 million houses have been constructed so far.

The Andhra Pradesh state government has set a target of building 2 million houses under the NTR Urban Housing Scheme before May 2019. These homes will be linked with the PMAY-Housing for all (Urban) scheme to secure subsidy, with the central government approving Rs 15.44 billion for construction. Each house will cost Rs 0.35 million and the central government will offer Rs 0.15 million and the state government will offer Rs 0.1 million. The beneficiaries will be given a loan worth Rs 75,000 and will only contribute Rs 25,000 (Gupta, 2018). The Andhra Pradesh government constructed 0.7 million and handed over to the poor people so far. It is planning to complete 0.3 million more houses by January 2019 . Even this scheme is not pool proof. There are accusations that non-beneficiaries are benefitting by $5 \%$.

\section{B. Saudi Arabia}

The present Saudi ownership of homes is 47 percent. The Saudi government wants to increase it to 70 percent by 2030 . Saudi Arabia unveiled a new housing program with 120 billion riyals as the Kingdom seeks to boost Saudi ownership (Editorial, 2018). For the borrowers, Saudi government is going to spend 120 billion Saudi riyals as subsidized home loans (Nereim, 2018).

As an economic transformation plan of vision 2030, Crown Prince Mohammed bin Salman has an especially sensitive plank of housing policy (Nereim, 2018). Under phase one of the 'My House' program in the next three years, Saudi Arabia's Ministry of Housing will hand over 120,000 housing units to its citizens (Staff Writer, 2017). The cost of the land has skyrocketed. On the other hand, the population is growing rapidly. All these factors will add more pressure on the economy to provide subsidized houses in the future.

\section{Subsidized Education}

\section{A. India}

Budget report of 2017 says, on education the central government of India is spending almost 80 billion (Shukla, 2017). In addition to the central government's subsidy on various education programs, individually state governments are spending a considerable percentage of the amount on education. There is opposition to public subsidization of education, specifically higher education. Private rates of return are more than the social rates of return to education. So, it is better that individuals should pay for their education and governments should reduce public subsidy (Psacharopoulos, 1994, The World Bank 1994).

\section{B. Saudi Arabia}

The kingdom is spending the highest on education in the world, an average of 10 percent on GDP, whereas advanced nations in Europe and North America spend an average of 4 to 5 percent. Mohammed (2013) says Saudi Arabia has allotted 204 billion riyals for the education sector in the 2013 budget. Saleh Abdul Kareem in his study found that the Saudi government spent 666 million riyals in 1970 it was 9.8 percent of the total budget and the literacy rate was 15 percent for men. As per World Bank data of 2009, the literacy rate is above 96.5 percent in Saudi Arabia and 25 percent of the total budget was allotted for education. Saudi government spent 90,000,620,000 riyals on education in 2010, which was increased to $124,319,484,000$ riyals in 2016 (table 3).

\section{Subsidized Healthcare}

\section{A. India}

"When addressing the wide range of social determinants of health, an equally wide range of policies needs to be considered" (Marmot, 2007 pp. 1153-1163). "In a general sense, social determinants of health consist of resources through which the individual can control and direct their conditions of life" (Fritzelland Lundberg, 2007 pp. 1-18).

In India, health care is free at public hospitals for all citizens. According to national accounts cell, ministry of health and family welfare, the government of India, different state governments and central government have spent 1806.56 billion rupees on healthcare in 2016-17. But Rao (2018) says individuals, pay 70\% of percent healthcare expenses from their pockets. The reason behind this is a poor quality of care in public hospitals. All high class and most of the middle class go to private hospitals. The Indian government recently launched its ambitious national health protection scheme - Ayushman Bharath. The scheme is going to be billed as the world's largest such government-run insurance scheme. It is good if they extend the scheme to the mid-class Indians.

\section{B. Saudi Arabia}

Saudi government spends a lot on subsidized healthcare. It is the largest in the Near East. 2018s budget of Saudi Arabia's largest share still accounts for healthcare and education spending at more than 36\% of the total budget (Export.gov, 2018).

Shujauddin (2014)says, in 2102, the Saudi government's Annual spending on healthcare was estimated at \$26.4 billion. In terms of expenditures, size, activity, and potential, the Saudi health-care sector remains the largest in the GCC region. 
Saudi government spent 22,808,200 riyals on health in 2007, which was increased to 67,758,793 riyals in 2017 (table 4 ). In ten years, the expenditure on health has increased to 3 folds.

\section{DISCUSSION}

Apart from the above-mentioned subsidies, the Indian Government has been offering goods and services such as free electricity to certain sections of the society, fertilizers to the farmers, and petroleum products to all on considerable subsidy. Similarly, Saudi Arabia is also giving subsidized petroleum products, electricity and cash to the citizens. Kingdom spent $\$ 60.9$ billion on fossil fuel subsidies in 2011. In fact, Saudi Arabia spent 10.6\% of GDP on fossil fuel subsidies that were more than what it had spent on health and education. Saudi Arabia stood second in the world on fossil fuel subsidies (Climate Scorecard, 2018).

Both these governments have been spending a lot of welfare schemes of their respective GDPs. The intention of these governments is to help the poor to lead a minimum quality of life. Though the intention is genuine and appreciable, in implementation two governments have not achieved any desired results even after 60 years of introduction.

However, social policy, if well designed, can be much more than a safety net and significantly contribute to product development (Chang, 2002). Educate the people about the burden of subsidies and the economic position of the respective countries. The Saudi government had taken a historical decision to introduce value-added tax from $1^{\text {st }}$ January 2018 . VAT revenues are estimated to be 40 billion Saudi riyals for 2018 (Staff Writer, 2017). Reuters_reported that to offset increasing costs of living because of VAT introduction Saudi Arabia plans to give its citizens 50 billion riyals in handouts (Perper, 2018). Pampering and subsidizing is not the way to run the country. Such actions by the government are beyond the common man's logic.

To some extent subsidies to the poor can be understandable, but historically, government subsidies extend the reaches not only to the poor people. In future demand could increase for subsidized health, state pensions, education, food, and housing. It is not prudent fiscally to encourage high long-term subsidy. How long these governments will continue like this? In India, taxpayers must take the burden of these subsidies. How long they can take the burden? Whereas the Saudi government must take the burden of the subsidies in Saudi Arabia.

First, by using technology, these governments can control the leakages and distortions to a large extent. India can learn from Saudi in using technology. Aadharcan is used like Saudi's national Id. For better results and to limit the leakages in the social welfare schemes, link aadhar, pan card and ration card (PDS).

Similarly, Saudi Arabia can also identify and target its population who needs to be helped more than others. Essentials like water, electricity, petrol are relatively cheap here in Saudi Arabia. And the prices are the same for the poor and rich alike. Now, Saudi Arabia can take a cue from the targeted PDS system of India and provide these necessities at a much lower price to its population defined by its own criteria. And it can sell its richer class the same things at a higher price. And in process, the state can not only help its unprivileged class but also generate higher incomes by taxing the richer class.

Secondly, redefine the poverty properly and by maintaining the precise data the governments can reduce the burden of subsidies. Next, governments can have a proper study by a group of experts on necessary subsidies and remove the other subsidies. Also, eliminate the petroleum subsidies by reducing the taxes on oil to a large extent. Finally, cash transfer is much better than the supply of goods as subsidies.

\section{CONCLUSION}

The growing population in these two countries put more pressure on subsidies on their respective economies. The proper study, wise measures, and quick actions will help these major nations in their regions to tackle the upcoming subsidy problem. Severe punishments to the people who enjoy illegal subsidies will send a strong message to society. Instead of focusing on giving subsidies, it is better to devise a strategy with a timeframe to reduce poverty by creating ample opportunity for the poor to improve their standard of living.

The direct beneficiaries of this study are the two countries compared in this study namely India and Saudi Arabia. Particularly the governments of these countries will certainly get benefited if they follow the suggestions given above such as using technology and targeted PDS systems, and both countries can learn from each other. There is no practical problem in implementing this study in their respective countries.

This study has its limitation as both the countries under study have different socio-economic statuses and different parameters to gauge under-privileged which makes a comparison to a great extent ineffective. This problem is compounded in the absence of uniform international standards to facilitate comparison. Nevertheless, this is a common criticism against all studies on international comparative analysis. This study analyses education, pension, health, food, and housing welfare schemes in a broad sense. There is a lot of scope for further study, each of the earlier mentioned aspects can be studied in great detail along with its impact on the beneficiaries.

\section{REFERENCES}

1. Al-Damigh, S.A., 2017. Sufficiency Line in Saudi Arabia. Riyadh: King Khalid Foundation 
2. Alsayyad, A.S., 2018. Social Protection in Saudi Arabia, Policy in Focus: International Policy Centre for Inclusive Growth 14(3): 64-67.

3. Augustine, 2016. Greying Saudi Arabia could multiply government's debt burden. Retrieved September 12, 2018, from https://gulfnews.com/business/greying-saudi-arabia-could-multiply-governments-debt-burden-1.1860458 pp. 1

4. Berry, A., 2013. Social protection, growth and employment: A conceptual framework. Retrieved September 14, 2018, from

5. http://www.undp.org/content/dam/undp/library/Poverty\%20Reduction/Inclusive\%20development/Social\%20prote ction,\%20growth\%20and\%20employment/Draft8_SPG\&E_web.pdf pp.1

6. Bohle, D. and B. Greskovits, 2007. Neoliberalism, embedded neoliberalism and neocorporatism: Towards transnational capitalism in Central-Eastern Europe. West European Politics 30(3): 443-466.

7. Bradshaw, J. and N. Finch, 2002. A Comparison of Child Benefit Packages in 22 Countries. University of York.

8. Chang, H. J., 2002. Kicking Away the Ladder?: Policies and Institutions for Economic Development in Historical Perspective. London: Anthem Press.

9. Climate Scorecard, 2018.Saudi Arabia subsidies. Retrieved October 12, 2018, from https://www.climatescorecard.org/2018/01/saudi-arabia-subsidies/pp.1

10. Crisil, 2015. Pension burden may rise to $4.1 \%$ of GDP by 2030: Crisil. Retrieved September 14, 2018, from https://www.businesstoday.in/money/investment/crisil-says-pension-burden-may-rise-gdp-by2030/story/214296.html pp. 1

11. Dobelniece, S., 2017. Social Assistance: Comparative Analysis. Economic Science for Rural Development No 46: 54-61.

12. Ebbinghaus, B., 2012. Comparing Welfare State Regimes:Are Typologies an Ideal or Realistic Strategy? European Social Policy Analysis Network, ESPAnet Conference, Edinburgh, UK.

13. Editorial, 2017. Saudi Agriculture Ministry won't withdraw bread subsidies. Retrieved October 22, 2018, from http://www.arabnews.com/node/1054156/saudi-arabia pp. 1

14. Editorial, 2018. Saudi Arabia unveils new housing programme to boost home ownership. Retrieved September 14, 2018,from https://www.thenational.ae/business/property/saudi-arabia-unveils-new-housing-programme-to-boosthome-ownership-1.702221 pp.1

15. ENS Economic Bureau, 2015. Subsidies helping the rich more: Economic Survey. Retrieved November 10, 2018, from https://indianexpress.com/article/business/budget/subsidies-helping-the-rich-more-economic-survey/ pp.1

16. Euvrard, F., 1989. 'Minimum income schemes: practical lessons'. Paper presented at the European Conference on Basic incomes, 15-17 November, Cumberland Lodge, UK.

17. Export.gov, 2018. Healthcare Resource Guide: Saudi Arabia. Retrieved October 19, 2018, fromhttps://2016.export.gov/industry/health/healthcareresourceguide/eg_main_108615.asppp.1

18. Fritzell. J., and O. Lundberg, (Eds.). 2007. Health, inequalities, welfare and resources. In:Fritzell J, Lundberg O, eds. Health inequalities and welfare resources. Bristol: Policy Press. 1-18. https://doi.org/10.1332/policypress/9781861347589.003.0001

19. Gayithri, K., 2007. A Study of Terminal Benefits of the Central Government Employees. New Delhi: Ministry of Finance, Government of India.

20. Goswami, R., 2001. Indian Pension System: Problems and Prognosis. Paper presented in the IAA Pensions Seminar, Brighton, June 5-7.

21. Guhan, S., 1994. Social Security Options for Developing Countries. International Labour Review $133(1), 35-54$.

22. Haggard, S., and R. Kaufman, 2008. Democracy, Development, and Welfare States: Latin America, East Asia and Eastern Europe. Princeton, NJ: Princeton Univ. Press

23. Hantrais, L., 1995. Comparative Research Methods. Social Research Update. Issue 13. University of Surrey. Retrieved: http://sru.soc.surrey.ac.uk/SRU13.html.

24. HelpAge India, 2007. The social pension in India: A participatory study on the poverty reduction impact and role of monitoring groups. Retrieved November 10, 2018, from http://www.helpage.org/silo/files/the-social-pensionin-india-a-participatory-study-of-the-poverty-reduction-impact-and-role-of-monitoring-groups.pdf pp. 1-8

25. Jacobs, D., 1998. Social Welfare Systems in East Asia. CASE Paper no.10, Centre for the Analysis of Social Exclusion, LSE, London.

26. Kabeer, N., 2002. Safety Nets and Opportunity Ladders: Addressing Vulnerability and Enhancing Productivity in South Asia. Working Paper 159, Institute of Development Studies. Brighton: University of Sussex. https://doi.org/10.1111/1467-7679.00191

27. Kaul, V., 2014. Required: A new poverty line that shows $67 \%$ of India is poor. Retrieved November 10,2018 , from https://www.firstpost.com/economy/required-a-new-poverty-line-that-shows-67-of-india-is-poor993241.html pp. 1 
28. Kaul, V., 2015. 7th Pay Commission Report: What does govt 'really' spend its money on? Retrieved November 7 , 2018, from https://www.equitymaster.com/dailyreckoning/detail.asp?date $=11 / 23 / 2015$ \& story $=5 \&$ title $=7$ th-PayCommission-Report-What-does-govt-really-spend-its-money-on pp. 1

29. Kennett, P., 2001. Comparative Social Policy: Theory and Research. Open University Press, Buckingham, Philadelphia.

30. Liebfried. S., 1991. Towards a European Welfare State: on integrating poverty, regimes, Centre for Social Policy Research Working Paper No.2, Bremen: University of Bremen.

31. Mabbett D. and H. Bolderson, 1999. 'Theories and methods in comparative social policy' in J Clasen, Ed, Comparative Social Policy: Concepts, Theories and Methods, Blackwell, Oxford

32. Marmot M., 2007. Achieving health equity: from root causes to fair outcomes. The Lancet 370(9593):1153-1163. https://doi.org/10.1016/S0140-6736(07)61385-3

33. Mohammed, I., 2013. Kingdom tops world in education spending. Retrieved November 10, 2018, from http://www.arabnews.com/saudi-arabia/kingdom-tops-world-education-spendingpp. 1

34. Nandi, A., 2016. Why pensions in India must not be given away for free. https://www.financialexpress.com/opinion/why-pensions-in-india-must-not-be-given-away-for-free/385602/pp. 1

35. Nereim, 2018. Saudi Arabia's \$32 Billion Bid to Build Private Mortgage Market. Retrieved December 1, 2018, from $\quad$ https://www.bloomberg.com/news/articles/2018-02-05/saudi-arabia-s-32-billion-bid-to-build-privatemortgage-market pp. 1

36. Perper, 2018. Saudi Arabia is giving many of its citizens $\$ 3000$ for free. Retrieved November 10, 2018, from https://www.aol.com/article/finance/2018/01/08/saudi-arabia-is-giving-many-of-its-citizens-dollar3000-forfree/23327277/pp. 1

37. Psacharopoulos, G., 1994. The perverse effects of public subsidization of education or How equitable is free education? Comparative education review 21: 69-90. https://doi.org/10.1086/445922

38. Ranganathan, N.M., 2017. Universal social pension for elderly individuals in India: Public expenditure requirements and fiscal sustainability. Indian Growth and Development Review, 10 (2): 89-116. https://doi.org/10.1108/IGDR-07-2017-0047

39. Rao, N. (2018, April 14). Who Is Paying for India's Healthcare? Retrieved September 12, 2018,from https://thewire.in/health/who-is-paying-for-indias-healthcare pp. 1

40. Schubert, B. C., and H. Martens, 2005. The Nordic Model: A Recipe for European Success? EPC Working Paper No.20. Retrieved September 12, 2018, from http://www.epc.eu/pub_details.php?pub_id=56\&cat_id=1 pp. 1

41. Sengoku, M., 2003. Emerging Eastern European Welfare States: A Variant of the "European" Welfare Model? Retrieved December 1, 2018, from http://srch.slav.hokudai.ac.jp/coe21/publish/no2_ses/3-2_Sengoku.pdf pp. 2-3

42. Sfakianakis, John., 2008. Saudi to spend $\$ 3$ bn on food subsidies. Retrieved December 1, 2018, from http://www.tradearabia.com/news/FOOD_144984.html pp. 1

43. Shujauddin, M., 2014. Saudi Arabia health care market overview. Retrieved December 1, 2018, from https://build.export.gov/build/groups/public/@eg_us_mn/documents/webcontent/eg_us_mn_080855.pdf pp. 6-16

44. Shukla, 2017. Budget 2017: Spend on education sector seen falling short. Retrieved September 12, 2018, from https://www.moneycontrol.com/news/business/economy/budget-2017-spendeducation-sector-seen-falling-short1004364.html pp. 1

45. Staff Writer, 2017. Saudi Arabia to spend \$32bn on housing for citizens. Retrieved September 12, 2018, from https://www.arabianbusiness.com/saudi-arabia-spend-32bn-on-housing-for-citizens-659663.htmlpp. 1

46. Staff Writer, 2017. All you need to know about taxes in Saudi Arabia. Retrieved December 4, 2018, fromhttp://english.alarabiya.net/en/business/economy/2017/08/27/All-you-need-to-know-about-taxes-in-SaudiArabia.htmlpp. 1

47. The World Bank, 1994. Higher Education: The lessons of experiences, Washington, DC.

48. The World Bank, 2008. The Performance of Social Pensions in India: The Case of Rajasthan. Retrieved December 1, 2018, from http://siteresources.worldbank.org/SOCIALPROTECTION/Resources/SP-Discussionpapers/Pensions-DP/0834.pdf pp. 9-14

49. The world Bank, 2011. Social protection for a changing India. Retrieved December 4, 2018, from http://www.worldbank.org/en/news/feature/2011/05/18/social-protection-for-a-changing-india pp. 1

50. The World Bank, 2017. Data: Population Density. Retrieved October 19, 2018, from https://data.worldbank.org/indicator/EN.POP.DNST pp. 1

51. The World Factbook, 2018. Guide to Country Comparisons: Central Intelligence Agency. Retrieved October 19, 2018, from https://www.cia.gov/library/publications/the-world-factbook/docs/rankorderguide.htmlpp. 1 


\section{APPENDIX}

Table 1: Saudi Arabian socio-economic indicators

\begin{tabular}{|c|c|c|c|c|}
\hline & $\begin{array}{l}\text { Expenditure on } \\
\text { Social Security \& } \\
\text { Welfare Services }\end{array}$ & $\begin{array}{l}\text { Expenditure on } \\
\text { Gross Domestic } \\
\text { Product (at } \\
\text { purchaser's value at } \\
\text { current price) }\end{array}$ & $\begin{array}{l}\text { Expenditure as a \% } \\
\text { of GDP }\end{array}$ & $\begin{array}{l}\text { Oil prices (Arabian } \\
\text { Light } 34 \mathrm{API} \text { ) }\end{array}$ \\
\hline & (i) & (ii) & (i) as a $\%$ of (ii) & \\
\hline 1985 & 359 & 376,318 & 0.095398 & 27.52 \\
\hline 1986 & 340 & 322,020 & 0.105584 & 13.73 \\
\hline 1987 & 349 & 320,931 & 0.108746 & 17.23 \\
\hline 1988 & 319 & 330,519 & 0.096515 & 13.40 \\
\hline 1989 & 320 & 357,065 & 0.08962 & 16.21 \\
\hline 1990 & 473 & 440,526 & 0.107372 & 20.82 \\
\hline 1991 & 677 & 495,177 & 0.136719 & 17.43 \\
\hline 1992 & 414 & 513,394 & 0.08064 & 17.94 \\
\hline 1993 & 400 & 497,965 & 0.080327 & 15.68 \\
\hline 1994 & 402 & 506,230 & 0.079411 & 15.39 \\
\hline 1995 & 533 & 536,820 & 0.099288 & 16.73 \\
\hline 1996 & 633 & 594,191 & 0.106531 & 19.91 \\
\hline 1997 & 823 & 621,534 & 0.132414 & 18.71 \\
\hline 1998 & 825 & 550,408 & 0.149889 & 12.20 \\
\hline 1999 & 583 & 606,439 & 0.096135 & 17.45 \\
\hline 2000 & 864 & 710,681 & 0.121574 & 26.81 \\
\hline 2001 & 860 & 690,516 & 0.124544 & 23.06 \\
\hline 2002 & 856 & 711,022 & 0.12039 & 24.32 \\
\hline 2003 & 962 & 809,279 & 0.118871 & 27.69 \\
\hline 2004 & 1150 & 970,283 & 0.118522 & 34.53 \\
\hline 2005 & 1149 & $1,230,771$ & 0.093356 & 50.21 \\
\hline 2006 & 1252 & $1,411,491$ & 0.088701 & 61.10 \\
\hline 2007 & 1,465 & $1,558,827$ & 0.093981 & 68.75 \\
\hline 2008 & 1301 & $1,949,238$ & 0.066744 & 95.16 \\
\hline 2009 & 1,391 & $1,609,117$ & 0.086445 & 61.38 \\
\hline 2010 & 1387 & $1,980,777$ & 0.070023 & 77.82 \\
\hline 2011 & 2039 & $2,517,146$ & 0.081004 & 107.82 \\
\hline 2012 & 3210 & $2,759,906$ & 0.116308 & 110.22 \\
\hline 2013 & 4,300 & $2,799,927$ & 0.153575 & 106.53 \\
\hline 2014 & 5221 & $2,836,314$ & 0.184077 & 97.18 \\
\hline 2015 & 4,216 & $2,453,512$ & 0.171835 & 49.85 \\
\hline 2016 & 3022 & $2,418,508$ & 0.124953 & 40.96 \\
\hline
\end{tabular}

Source: SAMA

Table 2: Panel A: Eligibility criteria for social pensions as of 2007

OAP DWP DIS

Demographic:

\begin{tabular}{|c|c|c|c|}
\hline Age & $>65$ years & Any age & $>8$ years \\
\hline Gender & -- & Female & -- \\
\hline \multicolumn{4}{|c|}{$\begin{array}{l}\text { Disability } \\
\text { The disability that prevents earning aliving (severity }=40 \% \text { ) }\end{array}$} \\
\hline Destitution & $\begin{array}{l}\text { No income } \\
\text { Below Pov } \\
\text { Saharia trib }\end{array}$ & $\begin{array}{l}\text { to maint } \\
\text { us (since } \\
\text { rrides all }\end{array}$ & $\begin{array}{l}\text { nself/herself } \\
\text { destitution/family criteria) }\end{array}$ \\
\hline
\end{tabular}


Family members: Husband dead or legally presumed dead No family member aged 20 years or older. Other family members missing for more than seven years. Other family members are also older than the old-age pension age limit and with no source of income or inability to earn due to disability.

State residence Resident of Rajasthan for more than three years.

Table 2: Panel B: Benefit level

\begin{tabular}{llllllll}
\hline & $\mathbf{1 9 7 4}$ & $\mathbf{1 9 7 9}$ & $\mathbf{1 9 8 6}$ & $\mathbf{1 9 8 8}$ & $\mathbf{1 9 8 9}$ & $\mathbf{2 0 0 5}$ & $\mathbf{2 0 0 7}$ \\
\hline OAP & 30 & 40 & 50 & 60 & 100 & 200 & 400 \\
\hline Joint OAP & 40 & 60 & 80 & 100 & 150 & 300 & TBC \\
\hline
\end{tabular}

Source: Government of Rajasthan, Department of Finance, government rules and orders, various years.

Table 3: Ministry of Education (General) Budget Year 1437-1438 (H)

\begin{tabular}{|c|c|c|c|c|c|}
\hline \multirow{3}{*}{$\begin{array}{l}\text { GREGORIAN } \\
\text { YEAR }\end{array}$} & \multirow[t]{3}{*}{ TOTAL } & \multicolumn{4}{|c|}{ MINISTRY OF EDUCATION FINANCIAL APPROVALS } \\
\hline & & \multicolumn{2}{|r|}{ Chapter - II } & Chapter - III & Chapter - IV \\
\hline & & $\begin{array}{c}\text { Salaries, } \\
\text { Allowances, } \\
\text { Wages }\end{array}$ & $\begin{array}{l}\text { Operational } \\
\text { Expenditure }\end{array}$ & $\begin{array}{l}\text { Programs and } \\
\text { Contracts } \\
\text { (Operations, } \\
\text { Maintenance, } \\
\text { Cleaning) }\end{array}$ & Projects \\
\hline 2010 & $90,000,620,000$ & $77,520,000,000$ & $4,685,235,000$ & $795,385,000$ & $7,000,000,000$ \\
\hline 2011 & $94.656,037,000$ & $80,011,242,000$ & $4,766,835,000$ & $925,560,000$ & $8,952,400,000$ \\
\hline 2012 & $101,466,583,000$ & $85,800,000,000$ & $5,608,623,000$ & $1,105,560,000$ & $8,952,400,000$ \\
\hline 2013 & $118,425,732,000$ & $102,560,000,000$ & $6,145,521,000$ & $1,620,211,000$ & $8,100,000,000$ \\
\hline 2014 & $121,253,000,000$ & $104,850,000,000$ & $6,646,000,000$ & $1,684,000,000$ & $8,073,000,000$ \\
\hline 2015 & $127,442,168,000$ & $107,431,073,000$ & $7,140,000,000$ & $3,094,610,000$ & $9,776,485,000$ \\
\hline 2016 & $124,319,484,000$ & $111,320,133,000$ & $6,565,316,000$ & $2,934,035,000$ & $3,500,000,000$ \\
\hline
\end{tabular}

Source: Ministry of Education, Saudi Arabia

Table 4: Table of MOH Budget (in thousands of riyals), compared to State Budget, over the years from 1427-1428 to 1438-1439H.:

\begin{tabular}{|c|c|c|c|c|c|c|c|}
\hline \multirow{2}{*}{$\begin{array}{c}\text { Gregorian } \\
\text { year }\end{array}$} & \multirow{2}{*}{$\begin{array}{l}\text { Total of the } \\
\text { State Budget }\end{array}$} & \multicolumn{6}{|c|}{ Appropriations for the Ministry of Health } \\
\hline & & $\begin{array}{c}\text { Total } \\
\text { Budget }\end{array}$ & $\begin{array}{l}* \text { Rate } \\
\text { in } \%\end{array}$ & Chapter I & Chapter II & Chapter III & $\begin{array}{c}\text { Chapter } \\
\text { IV }\end{array}$ \\
\hline 2007 & 380.000 .000 & 22.808 .200 & $6.0 \%$ & 11.527 .200 & 3.781 .000 & 5.200 .000 & 2.300 .000 \\
\hline 2008 & 450.000 .000 & 25.220 .000 & $5.6 \%$ & 12.392 .000 & 4.228 .000 & 6.000 .000 & 2.600 .000 \\
\hline 2009 & 475.000 .000 & 29.518 .700 & $6.2 \%$ & 14.391 .400 & 4.527 .300 & 7.760 .000 & 2.840 .000 \\
\hline 2010 & 540.000 .000 & 35.063 .200 & $6.5 \%$ & 17.150 .000 & 5.213 .200 & 9.560 .000 & 3.140 .000 \\
\hline 2011 & 580.000 .000 & 35.063 .200 & $6.9 \%$ & 19.207 .000 & 5.903 .200 & 11.210 .000 & 3.540 .000 \\
\hline 2012 & & 47.076 .447 & & 22.594 .000 & 6.850 .100 & 13.291 .755 & 4.340 .592 \\
\hline 2013 & & 54.350 .355 & & 25.200 .000 & 7.758 .600 & 16.391 .755 & 5.000 .000 \\
\hline 2014 & & 59.985 .360 & & 26.087 .630 & 8.492 .000 & 20.404 .543 & 5.001 .187 \\
\hline 2015 & & 62.342 .539 & & 26.666 .810 & 8.725 .303 & 21.898 .239 & 5.052 .187 \\
\hline 2016 & & $58,899,190$ & $7.01 \%$ & $26,103,790$ & $8,002,551$ & $22,992,849$ & $1,800,000$ \\
\hline 2017 & & $67,758,793$ & $7.61 \%$ & $27,412,949$ & $8,647,051$ & $27,507,479$ & $4,191,314$ \\
\hline
\end{tabular}

Source: Ministry of Health, Saudi Arabia 